\title{
PENINGKATAN KEMAMPUAN KOMUNIKASI INTERPERSONAL PADA SISWA SEKOLAH MENEGAH KEJURUAN (SMK) ' $X$ ' DI YOGYAKARTA MELALUI PELATIHAN ASERTIVITAS
}

\section{IMPROVEMENT OF INTERPERSONAL COMMUNICATION SKILL OF VOCATIONAL HIGH SCHOOL WITH ASSERTIVENESS TRAINING}

\author{
Arzia Purita \\ Sumedi P Nugraha \\ Uly Gusniarti \\ Fakultas Psikologi dan Ilmu Sosial Budaya Universitas Islam Indonesia Yogyakarta \\ Email: arziapurita03@gmail.com
}

\begin{abstract}
The purpose of this research was to empirically examine the effect of assertiveness training on the students interpersonal communication skills. The research design was pretes postest control group design. The subject determination into experimental group and control group. Interpersonal communication skills is measured by using scale interpersonal communication skills based on interpersonal communication aspects of DeVito (2011). Data analysis on this research was mixed design anova. The result of this research revealed the existance of interaction between time (pretest and posttest) and group (experimental and control) that was stated by $F=41,786 ; P=0,000$. The result showed that control group and experimental group was different. In this research, the asertiveness training treatment contribution toward the increasing of interpersonal communication skills is $79,1 \%$.
\end{abstract}

Key words: Asertiveness training, Interpersonal communication skill, Vocational high school.

\begin{abstract}
ABSTRAK
Penelitian ini bertujuan untuk menguji secara empiris pengaruh pelatihan asertivitas terhadap kemampuan komunikasi interpersonal pada 32 orang siswa kelas XI SMK ' $X$ ' Yogyakarta. Desain penelitian yang digunakan adalah pretest-posttest control group design (16 orang sebagai kelompok eksperimen dan 18 orang sebagai kelompok kontrol). Penelitian ini menggunakan analisis kuantitatif dan kualitatif. Analisis kuantitatif menggunakan uji mixed anova. Hasil analisis menunjukkan bahwa terdapat perbedaan yang signifikan pada kemampuan komunikasi interpersonal pada siswa antara kelompok eksperimen dan kelompok kontrol dengan nilai $F=41.786 ; p=0.000(p<0.005)$. Pelatihan asertivitas memberikan kontribusi sebesar 79,1\% terhadap peningkatan kemampuan komunikasi interpersonal yang dimiliki siswa.
\end{abstract}

Kata Kunci : Pelatihan Asertivitas, Komunikasi intepersonal, Siswa SMK.

SMK ' $X$ ' merupakan sekolah negeri yang terletak di daerah Sleman dan berada di pinggir jalan lingkar Yogyakarta. Terdapat empat jurusan di SMK tersebut, yaitu (i) Administrasi Perkantoran, (ii) Akuntansi, (iii) Pemasaran, (iv) Busana. Untuk menunjang aktivitas belajar, SMK " $X$ " memiliki 21 ruang kelas, 3 
ruang guru, 1 ruang BK, 4 ruang laboratorium, 1 ruang aula, 3 lapangan, taman, masjid, dan 2 pos jaga.

Berdasarkan hasil wawancara dan observasi dengan siswa dan pihak sekolah, diketahui bahwa banyak siswa terutama jurusan akuntansi yang mengalami kendala dalam melakukan komunikasi secara asertif dengan orang lain, sehingga sering terjadi kesalahpahaman yang diakibatkan oleh hal tersebut. Jurusan akuntasi berfokus pada konsentrasi, ketelitian, dan prinsip kerahasiaan dalam melakukan pembukuan perusahaan sehingga mereka jarang untuk melakukan diskusi ketika menemukan suatu soal atau permasalahan. Perilaku tersebut terbawa ketika mereka bersosialisasi dengan teman-teman di sekolah maupun dengan guru-guru.

Pada dasarnya pembelajaran jurusan akuntansi lebih menekankan kepada kemampuan berhitung dan ketelitian dalam melakukan pencatatan aktivitas ekonomi (Muawanah, 2008). Selain itu, pembelajaran akuntansi juga berpatokan kepada kode etik akuntan Indonesia yang mengharuskan siswa-siswa untuk dapat merahasiakan informasi keuangan perusahaan pada pihak ketiga (IAPI, 20072008). Hal tersebut secara tidak langsung memberikan pengaruh terhadap pola komunikasi sehari-hari siswa-siswa juru- san akuntansi yang cenderung lebih tertutup dan pasif dibandingkan dengan siswa jurusan lain.

Berdasarkan pemaparan di atas, terlihat pentingnya bagi siswa SMK untuk memiliki kemampuan komunikasi. Penelitian yang dapat dilakukan terkait dengan upaya untuk meningkatkan kemampuan komunikasi interpersonal siswa, salah satunya melalui pelatihan asertivitas. Pelatihan asertif dapat membantu mahasiswa untuk lebih terampil dan matang dalam menyampaikan ide/gagasan, serta mampu mengekspresikan diri dan perasaan yang dimilikinya tanpa ragu. Dengan asertivitas, seseorang menjadi lebih mampu terbuka, jujur, dan mengekspresikan dirinya dengan jelas, serta mengungkapkan perasaan, ide-ide dan pikirannya dengan tetap menghormati dan menghargai diri sendiri serta orang lain (Ress \& Graham, 1991).

Tujuan dari pelatihan asertivitas adalah untuk menumbuhkan kehidupan yang aktif dan penyesuaian diri yang adaptif dalam mengatasi kesulitan sosial, emosional, dan kecemasan (Walker, Clement, Hedberg, \& Wright, 1981). Melalui pelatihan asertivitas individu dapat membantu seseorang untuk mendapatkan hak-haknya secara sempurna dengan cara mengembangkan self esteem 
dan melibatkan ekspresi perasaan positif (Alberti \& Emmons, 2001).

Pada pelatihan asertivitas kali ini terdapat beberapa fokus pembelajaran yang dapat membantu meningkatkan kemampuan komunikasi seseorang. Materi pelatihan asertivitas pada penelitian ini didasarkan pada aspek-aspek asertivitas yang dijelaskan oleh Alberti dan Emmons (2001) yaitu meliputi: (a) Meningkatkan kemampuan untuk memahami kesetaraan dalam hubungan antar manusia, (b) Meningkatkan kemampuan untuk menyadari mengenai kelemahan dan kelebihan yang dimiliki, (c) Meningkatkan kemampuan untuk mengungkapkan perasaan secara langsung, (d) Meningkatkan kemampuan untuk mempertahankan hak-hak pribadi.

Berdasarkan penjelasan di atas, hipotesis yang diajukan dalam penelitian ini adalah ada pengaruh positif pelatihan asertivitas terhadap kemampuan komunikasi interpersonal pada siswa SMK ' $X$ '. Siswa yang diberikan pelatihan asertivitas akan mengalami peningkatan kemampuan komunikasi interpersonal dibandingkan dengan siswa yang tidak mendapatkan pelatihan asertivitas.

\section{METODE PENELITIAN}

\section{Desain Penelitian}

Penelitian ini melibatkan 32 orang siswa kelas XI di SMK ' $X$ ' Yogyakarta, yaitu 16 orang siswa bertindak sebagai kelompok eksperimen dan 16 orang siswa bertindak sebagai kelompok kontrol. Adapun karakteristik subjek sebagai berikut: 1) siswa-siswi jurusan akuntansi; 2) skor skala kemampuan komunikasi interpersonal dengan skor sedang hingga rendah.

Tabel 1. Desain penelitian

\begin{tabular}{lccc}
\hline Kelompok & Prates & Perlakuan & Pascates \\
\hline Eksperimen & O1 & $\mathrm{X}$ & O2 \\
Kontrol & O1 & - & O2 \\
\hline
\end{tabular}

Keterangan:

O1 : Prates

$\mathrm{O} 2$ : Pascates

$\mathrm{X}$ : Perlakuan (pelatihan asertivitas)

- : Tanpa perlakuan 


\section{Prosedur Intervensi}

Pelatihan asertivitas adalah suatu kegiatan perlakuan sistematis yang bertujuan membantu siswa SMK jurusan akuntansi agar mampu untuk mengungkapkan pikiran, ide, dan perasaan secara langsung dengan cara yang tepat, serta tetap menghargai diri sendiri dan orang lain. Pelatihan asertivitas ini dilaksanakan sebanyak 4 sesi selama 2 hari. Sesi pertama adalah memahami kesetaraan hubungan, sesi ini bertujuan untuk membantu siswa dalam memahami mengenai kesamaan posisi dalam berinteraksi sosial. Sesi kedua adalah membangun kesadaran diri, sesi ini bertujuan untuk membantu siswa mengidentifikasikan tingkat asertivitas yang dimilikinya dalam berkomunikasi. Sesi ketiga adalah mengekspresikan diri, sesi ini bertujuan untuk membantu siswa mendeskripsikan emosi yang dirasakannya serta membantu siswa untuk mengekspresikan emosinya secara asertif dalam berbagai situasi. Sesi keempat adalah memahami hak-hak pribadi, sesi ini bertujuan untuk membantu siswa memahami hak-hak dalam berkomunikasi.

\section{Metode Analisis Data}

Analisis data yang digunakan dalam penelitian ini adalah analisis statistik dengan menggunakan anava campuran (mixed anova). Teknik analisa ini digunakan untuk membandingkan kemampuan komunikasi interpersonal sebelum dan sesudah perlakuan antara kelompok eksperimen dan kelompok kontrol. Teknik analisa ini memadukan dua sub analisis yaitu Within Subject Test dan Between Subject Test. Within Subject Test adalah pengujian perbedaan skor dalam satu kelompok (prates dan pascates) dan Between Subject Test adalah pengujian perbedaan skor antar kelompok (eksperimen dengan kontrol).

\section{HASIL PENELITIAN}

\section{Deskripsi Statistik}

Berdasarkan hasil analisis diperoleh data statistik deskriptif yang disajikan dalam tabel berikut ini : 
Tabel 2. Deskripsi Data

\begin{tabular}{lllll}
\hline & Group & Mean & Std. Deviation & $\mathbf{N}$ \\
\hline \multirow{3}{*}{ Prates } & Eksperimen & 1.0150 & 5.95539 & 16 \\
& Kontrol & 1.0037 & 8.25328 & 16 \\
\cline { 2 - 5 } Pascates & Total & 1.0094 & 7.10265 & 32 \\
\hline \multirow{3}{*}{ Tindak lanjut } & Eksperimen & 1.1625 & 9.23400 & 16 \\
& Kontrol & 99.81 & 6.88204 & 16 \\
\cline { 2 - 5 } & Total & 1.0803 & 11.57161 & 32 \\
\hline & Kosperimen & 1.1988 & 9.78349 & 16 \\
& Kontrol & 1.0075 & 7.434416 & 16 \\
\cline { 2 - 5 } & Total & 1.1031 & 12.94015 & 32 \\
\hline
\end{tabular}

Tabel 2 di atas menunjukkan bahwa rerata prates kelompok eksperimen sebesar 1.0150, pascates sebesar 1.1625 serta rerata tindak lanjut sebesar 1.1988. Hal ini menunjukkan bahwa terjadi peningkatan kemampuan komunikasi interpersonal pada saat pretest, posttest dan tindak lanjut. Sementara itu pada kelompok kontrol terjadi penurunan rerata kemampuan komunikasi interpersonal pada saat pretest, pascatest, dan tindak lanjut. Pada saat prates skor yang diperoleh kelompok kontrol sebesar 1.0037, pascates sebesar 99.81, dan tindak lanjut sebesar 1.0075 .

\section{Hasil Uji Prasyarat}

Uji prasyarat dengan menguji normalitas dan homogenitas data dilakukan sebelum pengujian hipotesis. Pengujian ini didasari oleh asumsi dasar asumsi dasar parametrik, yakni data terdistribusi normal dan nilai variannya homogen.

Tabel 3. Rangkuman Uji Normalitas

\begin{tabular}{llll}
\hline & PRATES & PASCATES & TINDAK LANJUT \\
\hline Kolmogorov-Smirnov & .587 & .784 & .585 \\
Asymp. Sig. (2-tailed) & .881 & .631 & .884 \\
\hline
\end{tabular}

Tabel 3 di atas, dapat dijelaskan bahwa sebaran skor pada data prates, pascates, dan tindak lanjut skala data normal $(p>0.05)$. kemampuan komunikasi interpersonal kedua kelompok menunjukkan sebaran 
Tabel 4. Tabel Uji Homogenitas (Levene's Test of Error Variances)

\begin{tabular}{lcccc}
\hline & F & df1 & df2 & Sig. \\
\hline $\begin{array}{l}\text { Skor kemampuan komunikasi } \\
\text { Interpersonal Prates }\end{array}$ & .710 & 1 & 30 & .406 \\
\hline $\begin{array}{l}\text { Skor kemampuan komunikasi } \\
\text { Interpersonal Pascates }\end{array}$ & 1.021 & 1 & 30 & .320 \\
\hline $\begin{array}{l}\text { Skor kemampuan komunikasi } \\
\text { Interpersonal Tindak lanjut }\end{array}$ & .936 & 1 & 30 & .341 \\
\hline
\end{tabular}

Berdasarkan data diatas, dapat pemberian pelatihan asertivitas terhadap diketahui bahwa nilai Levene statistic peningkataan kemampuan komunikasi pada kedua kelompok saat prates $\mathrm{p}=$ interpersonal, di mana kemampuan 0.406 ( $p>0.05)$, pascates $p=0.320$ komunikasi interpersonal pada kelompok $(p>0.05)$, dan nilai pada saat tindak eksperimen akan lebih meningkat setelah lanjut $p=0.341(p>0.05)$. Hal tersebut menunjukkan bahwa populasi kelompok responden data penelitian ini memiliki homogenitas dalam ragam yang sama.

\section{Hasil Uji Hipotesis}

Hipotesis yang diajukan dalam penelitian ini adalah ada pengaruh pada tabel 5 berikut :

Tabel 5. Hasil Uji Hipotesis

\begin{tabular}{llllll}
\hline Source & $\begin{array}{l}\text { Type III Sum } \\
\text { Of Square }\end{array}$ & Df & $\begin{array}{l}\text { Mean } \\
\text { Square }\end{array}$ & F & Sig. \\
\hline Waktu & 1529.771 & 1.558 & 981.814 & 42.374 & 0.000 \\
Waktu*Kelompok & 1508.521 & 1.558 & 968.176 & 41.786 & 0.000 \\
Error (Waktu) & 1083.042 & 46.743 & 23.170 & & \\
\hline
\end{tabular}

Pada tabel 5, baris time*kelompok diketahui nilai $F=41.786$ dan nilai $p=$ $0.000(p<0.05)$. Nilai tersebut dapat diartikan sebagai adanya interaksi antara waktu pengukuran (prates, pascates, dan tindak lanjut) dan kelompok (eksperimen dan kontrol). Interaksi tersebut menunjukkan bahwa terdapat peningkatan skor yang berbeda secara signifikan dari prates, pascates, dan tindak lanjut antara 
kedua kelompok. Setelah diketahui maka langkah selanjutnya adalah melihat bahwa terjadi interaksi yang signifikan efektivitas intervensi. Efektivitas interantara time (prates, pascates, tindak vensi dapat dilihat pada tabel 6 berikut lanjut) dan group (eksperimen-kontrol), ini :

Tabel 6. Pairwise Comparison

\begin{tabular}{|c|c|c|c|c|c|c|c|}
\hline \multirow[t]{2}{*}{ Group } & \multirow[t]{2}{*}{$\begin{array}{l}\text { (I) } \\
\text { time }\end{array}$} & \multirow[t]{2}{*}{$\begin{array}{l}\text { (J) } \\
\text { time }\end{array}$} & \multirow{2}{*}{$\begin{array}{l}\text { Mean } \\
\text { Difference } \\
(\mathrm{I}-\mathrm{J})\end{array}$} & \multirow[t]{2}{*}{$\begin{array}{l}\text { Std. } \\
\text { Error }\end{array}$} & \multirow[t]{2}{*}{ Sig } & \multicolumn{2}{|c|}{$\begin{array}{l}95 \% \text { Confidence Interval } \\
\text { For Difference }\end{array}$} \\
\hline & & & & & & $\begin{array}{l}\text { Lower } \\
\text { Bound }\end{array}$ & BoundUpper \\
\hline \multirow{6}{*}{ Eksperimen } & 1 & 2 & -14.750 & 1.457 & .000 & -17.726 & -11.774 \\
\hline & & 3 & -18.375 & 1.832 & .000 & -22.117 & -14.633 \\
\hline & 2 & 1 & 14.750 & 1.457 & .000 & 11.774 & 17.726 \\
\hline & & 3 & -3.625 & 1.135 & .003 & -5.944 & -1.306 \\
\hline & 3 & 1 & 18.375 & 1.832 & .000 & 14.633 & 22.117 \\
\hline & & 2 & 3.625 & 1.135 & .003 & 1.306 & 5.944 \\
\hline \multirow{6}{*}{ Kontrol } & 1 & 2 & .562 & 1.457 & .702 & -2.413 & 3.538 \\
\hline & & 3 & -.375 & 1.832 & .839 & -4.117 & 3.367 \\
\hline & 2 & 1 & -.562 & 1.457 & .702 & -3.538 & 2.413 \\
\hline & & 3 & -.938 & 1.135 & .415 & -3.256 & 1.381 \\
\hline & 3 & 1 & .375 & 1.832 & .839 & -3.367 & 4.117 \\
\hline & & 2 & .938 & 1.135 & .415 & -1.381 & 3.256 \\
\hline
\end{tabular}

Tabel 6 di atas menunjukkan bahwa perubahan kemampuan komunikasi interpersonal pada kelompok eksperimen adalah signifikan dengan nilai $\mathrm{p}=.000(\mathrm{p}<0.05)$ pada saat prates, pascates, tindak lanjut. Pada saat pascates dan tindak lanjut nilai $\mathrm{p}$ yang juga signifikan yaitu $p=.003(p<0.05)$. Hal ini menunjukkan bahwa pelatihan asertivitas dapat meningkatkan kemampuan komunikasi interpersonal pada kelompok eksperimen, sedangkan pada kelompok kontrol tidak terjadi peningkatan yang signifikan pada kemampuan komunikasi interpersonal yang dimiliki, hal tersebut ditandai dengan nilai $p$ $>0.05$. Dengan demikian dapat disimpulkan bahwa ada pengaruh pemberian pelatihan asertivitas terhadap peningkatan kemampuan komunikasi interpersonal pada kelompok eksperimen yang mendapatkan pelatihan asertivitas.

Selanjutnya pelatihan asertivitas sendiri memberikan kontribusi sebesar $79,1 \%$ terhadap peningkatan kemampuan komunikasi interpersonal yang dimiliki oleh kelompok eksperimen. Hal tersebut dapat dilihat melalui hasil analisis statistik pada tabel 7 berikut: 
Tabel 7. Hasil Analisis Multivariate test

\begin{tabular}{lllllll}
\hline Kelompok & & Value & F & Sig. & $\begin{array}{l}\text { Partial } \\
\text { Squared }\end{array}$ & Eta \\
\hline Eksperimen & Pillai's trace & .791 & 54.993 & .000 & .791 \\
& Wilks's lambda & .209 & 54.993 & .000 & .791 \\
& Hotelling's trace & 3.793 & 54.993 & .000 & .791 \\
& Roy's largest root & 3.793 & 54.993 & .000 & .791 \\
\hline Kontrol & Pillai's trace & .027 & .397 & .676 & .027 \\
& Wilks's lambda & .973 & .397 & .676 & .027 \\
& Hotelling's trace & .027 & .397 & .676 & .027 \\
& Roy's largest root & .027 & .397 & .676 & .027 & \\
\hline
\end{tabular}

Pada tabel 7, baris eksperimen Wilks' lambda diketahui nilai partial Eta Squared $=0.791$. Hal tersebut menunjukkan bahwa pelatihan asertivitas memberikan kontribusi sebesar 79,1\% terhadap peningkatan skor komunikasi interpersonal pada kelompok eksperimen.

\section{PEMBAHASAN}

Penelitian ini bertujuan untuk mengetahui efektivitas pelatihan asertivitas dalam meningkatkan kemampuan komunikasi interpersonal siswa SMK. Berdasarkan data prates dan pretes skala komunikasi interpersonal diperoleh nilai $F=41.786$ dengan $p=0,000$ (nilai sig<0,05). Nilai tersebut membuktikan bahwa terdapat perubahan skor kemampuan komunikasi interpersonal pada kelompok eksperimen dan kelompok kontrol. Kelompok eksperimen meng- alami perubahan skor yang lebih besar setelah mendapatkan pelatihan asertivitas dibandingkan kelompok kontrol yang tidak mendapatkan pelatihan asertivitas.

Diterimanya hipotesis penelitian yang diajukan dalam penelitian ini sesuai dengan penelitian Al'aim dan Mulyana (2013). Asertivitas berkaitan dengan tingkah laku dalam hubungan interpersonal yang ditandai dengan kemampuan seseorang mengekspresikan pikiran, perasaan, dan keyakinan yang diungkapkan secara langsung, jujur, tepat, dan tidak melanggar hak asasi orang lain (Miasari, 2012). Oleh karena itu, untuk meningkatkan kemampuan komunikasi interpersonal dapat dilakukan dengan berbagai macam pelatihan, salah satunya pelatihan asertivitas (Al'aim \& Mulyana, 2013).

Terdapat dua hal yang berperan mengapa pelatihan asertivitas dapat meningkatkan kemampuan komunikasi 
interpersonal pada siswa kelas XI SMK. Pertama, secara teknis, yaitu bagaimana proses intervensi dilakukan. Hasil evaluasi pelatihan dari responden penelitian jika dilihat dari aspek trainer dinilai oleh 12 responden penelitian $(75 \%)$ sangat baik, dan 4 responden penelitian lainnya (25\%) baik. Sedangkan dari aspek materi yang diberikan sebanyak 10 responden penelitian $(62,5 \%)$ memberikan penilaian sangat baik, dan 6 responden lainnya $(37,5 \%)$ memberikan penilaian baik. Pada aspek penyelenggaraan 6 responden penelitian $(37,5 \%)$ memberikan penilaian baik dan 10 responden penelitian lainnya $(62,5 \%)$ memberikan penilaian sangat baik. Hal tersebut menunjukkan bahwa secara keseluruhan, pelatihan yang diberikan menurut persepsi responden pelatihan sudah dipandang baik.

Kedua, secara konseptual, yaitu bagaimana pelatihan yang diberikan dapat memberikan pengaruh kepada responden penelitian atau dengan kata lain dapat meningkatkan kemampuan komunikasi interpersonal. Pendekatan pelatihan dipilih karena pelatihan merupakan suatu metode pembelajaran yang bertujuan untuk mengubah aspek kognitif, afektif serta hasil keterampilan atau keahlian (Kikpatrick dalam Salas dkk, 2011). Pelatihan asertivitas dirancang berdasarkan teori cognitive behaviour. Teori ini menjelaskan bahwa proses kognitif menjadi faktor penentu dalam proses individu berfikir, merasa, dan bertindak. Pada pelatihan ini responden pelatihan diarahkan untuk memodifikasi fungsi berfikir, merasa, dan bertindak. Dengan mengubah perasaan dan pikirannya, diharapkan responden penelitian mampu mengubah perilakunya ke arah yang lebih baik (Oemarjoedi, 2003).

Setiono dan Permadi (2005) mengatakan asertivitas bukanlah sesuatu yang sudah ada sejak lahir, sehingga diperlukan pelatihan asertivitas untuk membentuk dan membiasakan individu berperilaku asertif. Wolpe (Rakos, 1991) menjelaskan bahwa asertivitas dapat diartikan sebagai ekspresi emosi tegas terhadap orang lain, dan dalam konteks komunikasi interpersonal berarti pula mampu untuk mengkomunikasikan perasaan, pikiran dan keinginan dengan jujur dan langsung. Pernyataan Wolpe tersebut sejalan dengan pertanyataan yang disampaikan oleh Zasttrow (Nursalim, 2005) yang menjelaskan bahwa pelatihan asertivitas dirancang untuk membimbing seseorang menyatakan, merasa, dan bertindak pada asumsi bahwa mereka memiliki hak untuk untuk menjadi dirinya sendiri dan untuk 
mengekspresikan perasaannya secara bebas.

Teori cognitive behaviour turut digunakan dalam pelatihan ini. Hal ini terdapat pada sesi pertama, yaitu equality yang berisi mengenai materi kesetaraan hubungan dalam berkomunikasi. Carl Rogers menjelaskan bahwa kesetaraan dapat diartikan sebagai sebuah sikap untuk memberikan penghargaan secara positif dan tidak bersarat kepada orang lain (De Vito, 1997). Responden penelitian diberikan pemahaman bahwa dalam berkomunikasi harus selalu ada kesetaraan, yaitu memperlakukan orang lain secara horizontal, dan demokratis. Dengan adanya kesetaraan dalam berkomunikasi maka setiap pihak yang terlibat dalam komunikasi tidak saling menggurui akan tetapi berbicara pada tingkat yang sama, sehingga hal tersebut akan membentuk sikap saling menghargai dan menghormati terhadap perbedaan dan keyakinan yang ada atau oleh Alberti dan Emmons (Uyun, 2003) disebut dengan kondisi win-win solution.

Selanjutnya pada sesi kedua, yaitu who $i$ am, yang berisi materi mengenai kesadaran diri dengan mengenali kelemahan dan kelebihan diri berdasarkan perspektif orang lain dan diri sendiri. Responden pelatihan diajak untuk mampu mengidentifikasikan apakah perilaku- nya sudah cukup efektif dalam berkomunikasi dengan orang lain (asertif atau tidak asertif). Harapannya ketika responden penelitian sudah mengetahui mengenai tingkat asertivitasnya, maka responden tersebut akan mampu mengontrol hidupnya, mampu mengatasi problem, mampu mengambil keputusan, menjadi lebih percaya diri, aktif, dan optimis. Bloom (Afiatin, 2008) menjelaskan bahwa dengan mampu mengenal diri sendiri secara baik, seseorang akan mampu untuk menentukan pilihan, keinginan, dan tujuan hidupnya tanpa harus dipengaruhi oleh orang lain, sehingga individu tersebut akan menjadi individu yang lebih asertif. Hal tersebut sejalan dengan penjelasan Uyun (2003) yang menyatakan bahwa asertivitas akan meningkatkan kemampuan individu dalam menjalin hubungan dengan orang lain. Dalam konteks pelatihan ini adalah hubungan komunikasi dengan orang lain.

Sesi ketiga, yaitu express your self, berisi materi mengenai mengekspresikan diri dan pikiran. Pada sesi ketiga responden penelitian diberikan penjelasan mengenai respon emosi yang terbentuk dikarenakan oleh proses berfikir. Selain itu responden pelatihan juga diberikan contoh dan melakukan role play mengenai cara-cara untuk mengekspresikan emosi dan pikirannya secara 
asertif sehingga tidak menyinggung perasaan orang lain. Mengekspresikan emosi dan pikiran penting dalam berkomunikasi agar komunikasi dapat berjalan lebih efektif. Hal tersebut dikarenakan tidak ada emosi ataupun pikiran yang disembunyikan antara komunikator dan komunikan, sehingga akan muncul suasana yang mendukung dan posiitif dalam berkomunikasi (DeVito, 1997).

Kemudian sesi terakhir, yaitu my own right, berisi materi mengenai hak dan kewajiban dalam berkomunikasi. Responden pelatihan diajak untuk memahami hak dan kewajiban dalam berkomunikasi serta respons dasar yang dapat digunakan untuk mempertahankan hak berkomunikasi yang dilanggar. Responden pelatihan diberikan tayangan mengenai hak dalam berkomunikasi, kemudian berdiskusi mengenai tayangan tersebut. Alberti dan Emmons (Uyun, 2003) menjelaskan bahwa asertivitas menekankan pada penghargaan terhadap hak yang dimiliki oleh orang lain. Oleh karena itu, melalui pembelajaran mengenai hak-hak dalam berkomunikasi, responden pelatihan mampu untuk menyelesaikan masalah yang muncul dengan cara yang asertif dan tidak menyakiti lawan bicaranya.
Berdasarkan empat sesi pelatihan asertivitas tersebut di atas, responden pelatihan diajarkan untuk dapat memahami mengenai kesetaraan dalam berkomunikasi, menyadari tipe berkomunikasi yang dimiliki, memahami cara-cara mengekspresikan diri dalam berkomunikasi, serta memahami hak dan kewajiban dalam berkomunikasi. Dalam konteks pelatihan ini, responden dilatih dengan mengerjakan lembar kerja, role play, dan diskusi. Dalam penelitian ini, responden penelitian mengalami peningkatan skor komunikasi interpersonal pada saat posttest maupun pada saat tindak lanjut. Namun terdapat beberapa subjek yang tidak mengalami kenaikan skor pada saat tindak lanjut, hal tersebut mungkin dipengaruhi oleh beberapa hal yang tidak dapat dikontrol peneliti.

\section{SIMPULAN DAN SARAN}

\section{Simpulan}

Berdasarkan hasil analisis data dan pembahasan yang dilakukan setelah pelatihan, maka dapat disimpulkan pelatihan asertivitas memberikan pengaruh terhadap peningkatan kemampuan komunikasi interpersonal pada siswa kelas XI SMA "X" Yogyakarta. Terdapat peningkatan skor kemampuan komunikasi interpersonal pada siswa, sebelum 
(pretest), setelah pelatihan (posttest), dan dua minggu setelah pelatihan (tindak lanjut). Selain itu, berdasarkan analisis kualitatif, diketahui bahwa siswa mendapatkan beberapa manfaat selama mengikuti pelatihan, seperti misalnya mengetahui cara untuk berkomunikasi secara lebih baik dan asertif, memiliki keberanian untuk mengungkapkan pendapat dan pikirannya kepada orang lain, menjadi lebih mampu untuk menghormati orang lain ketika berkomunikasi, serta menjadi lebih mampu untuk mengontrol emosi pada saat berkomunikasi.

\section{Saran}

Untuk pihak sekolah yaitu bahwa hasil penelitian ini menunjukkan kemampuan komunikasi interpersonal yang dimiliki oleh siswa kelas XI SMK " $X$ " dapat ditingkatkan, salah satu caranya adalah dengan memberikan pelatihan asertivitas. Oleh karena itu, disarankan kepada pihak sekolah untuk terus memberikan pengarahan kepada siswa dengan mengacu pada modul pelatihan yang telah disusun peneliti. Untuk peneliti selanjutnya disarankan: (1) Dapat melakukan penelitian ulang (replikasi penelitian) dengan menggunakan responden yang lebih bervariasi; (2) Apabila akan melakukan pengem-bangan pada modul pelatihan disarankan untuk tetap merujuk pada teori atau penelitian yang sesuai; (3) Dipersilahkan untuk menggunakan ataupun mengembangkan alat ukur yang telah disusun oleh peneliti dengan menggunakan responden penelitian lebih banyak dari jumlah responden yang dilibatkan dalam penelitian yang telah dilakukan peneliti;

Dipersilahkan untuk mengubah pernyataan dalam skala kemampuan komunikasi interpersonal agar dapat lebih sesuai dengan aspek yang ada.

\section{DAFTAR PUSTAKA}

Al'ain, M. O., \& Mulyana, O. P. (2013). Pelatihan Asertif Untuk Meningkatkan Komunikasi Interpersonal Anggota HIMA (Himpunan Mahasiswa) Prodi Psikologi FIP UNESA. Character, 2 (1),1-6.

Alberti, R., \& Emmons, M. (2001). Your Perfect Right (Panduan Praktis Hidup Lebih Ekspresif dan Jujur pada Diri Sendiri). Terjemahan : Ursula G. Buditjahja. Jakarta: PT Elex Media Komputindo.

Azwar, S. (2011). Penyusunan Skala Psikologi. Yogyakarta: Pustaka Pelajar.

DeVito, J. A. (1997). Komunikasi Antar Manusia (Terjemahan oleh : 
Maulana, A). Jakarta: Profesional Books.

Muawanah, U. (2008). Konsep Dasar Akuntansi dan Pelaporan Keuangan. Klaten: Macanan Jaya Cemerlang.

Oemarjadi, A. (2003). Pendekatan Cognitive Behavior Dalam Psikoterapi. Jakarta : Creative Media.

Rakos, R. (1991). Assertive Behavior: Theory Research \& Training . New York: Routledge, Chapman \& Hill Inc.

Rees, S., \& Graham, R. S. (1991). Asertion Training, How To Be Who You Really Are. London and New York: Routledge, Chapman and Hall Inc.
Setiono, V., \& Pramadi, A. (2005). Pelatihan Asertivitas dan Peningkatan Perilaku Asertif Pada SiswaSiswi. Anima Indonesian Psychology Journal, 20 (2), 149-148.

Uyun, Q. (2003). Pelatihan Asertivitas Untuk Meningkatkan Ketahanan Istri Terhadap Tindak Kekerasan Suami. Tesis. (Tidak Diterbitkan). Yogyakarta: Universitas Gajah Mada.

Walker, C., Clement, P., Hedberg, A., \& Wright, L. (1981). Clinical Procedures for Behaviot Therapy. New Jersey: Prentice Hall, Inc. Englewood Cliffs. 